\title{
Superoxide Anion Generation in Human Milk Macrophages: Opsonin-Dependent Versus Opsonin-Independent Stimulation Compared with Blood Monocytes
}

\author{
RÜDIGER ADAM, FRANK KUCZERA, HENRIK KÖHLER, AND HORST SCHROTEN
}

Zentrum für Kinderheilkunde, Heinrich-Heine-Universität, 40225 Düsseldorf, Germany

\section{ABSTRACT}

\begin{abstract}
Macrophages are believed to play an important role within the immunoprotective effects of human breast milk. It was the purpose of this study to evaluate the capability of human milk macrophages $(M M \Phi)$ to generate superoxide anions $\left(\mathrm{O}_{2}^{-}\right)$in comparison with peripheral blood monocytes (BMo) after stimulation with opsonized and unopsonized zymosan. Potential inhibitors of attachment and phagocytosis such as mannose and cytochalasin B were used. Expression of the mannose receptor on MM $\Phi$ was demonstrated by staining with MAb. BMo generated more $\mathrm{O}_{2}^{-}$than $\mathrm{MM \Phi} \mathrm{(417 \pm 79} \mathrm{versus} 216 \pm 15 \mathrm{nmol} \mathrm{O}{ }_{2}^{-} / \mathrm{mg}$ protein, $p<0.05$ ) after stimulation with opsonized zymosan. When unopsonized zymosan was used as a serum-independent stimulus, BMo generated slightly less $\mathrm{O}_{2}^{-}$in comparison with MMФ (150 \pm 34 versus $176 \pm 18 \mathrm{nmol} \mathrm{O}_{2}{ }^{-} / \mathrm{mg}$ protein, $p<$ $0.05)$. These findings imply a higher proportion of opsoninindependent phagocytosis in $\mathrm{MM} \Phi$ than in $\mathrm{BMo}$ (82 versus $36 \%)$. Preincubation with mannose resulted in a significantly higher reduction of $\mathrm{O}_{2}{ }^{-}$generation in $\mathrm{MM} \Phi$ compared with BMo stimulated with opsonized zymosan, whereas no difference was
\end{abstract}

found when unopsonized zymosan was used. After addition of cytochalasin $\mathrm{B}$, equal inhibition of $\mathrm{O}_{2}{ }^{-}$generation was observed regardless of the cell type or stimulus used. Thus, MMФ are stimulated to a greater extent by serum-independent mechanisms than BMo. As opsonins like complement or $\operatorname{IgG}$ are rare in the colostrum and the neonatal intestinal environment, such a differentiation toward serum-independent phagocytic abilities could play an important role for protective functions of human ММФ. Possible involvement of the mannose receptor and the $\beta$-glucan receptor in this specialization are discussed. (Pediatr Res 49: 435-439, 2001)

ММФ, milk macrophages

BMo, blood monocytes

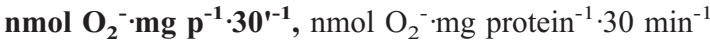

MR, mannose receptor

CR3, complement receptor type 3
Besides well-known nutritional benefits, transfer of antimicrobial activity is of great importance in infant breast-feeding. A great variety of humoral defense factors (e.g. secretory Ig, especially sIgA, lactoferrin, lysozyme, oligosaccharides, mucins, and others) contribute to the beneficial effects. In addition, large numbers of viable cells are present in human colostrum and breast milk with a high proportion of macrophages likely being responsible for antiinfectious properties.

These human $M M \Phi$ with a diameter of 18 to $40 \mu \mathrm{m}$ contain a high amount of phagocytosed lipids, "foamy cells." Their morphologic and cytochemical properties are similar to differentiated macrophages. For example, they bear $\mathrm{Fc}$ receptors for

Received February 29, 2000; accepted September 22, 2000

Correspondence: Horst Schroten, M.D., Zentrum für Kinderheilkunde, Heinrich-HeineUniversität, Düsseldorf, Moorenstraße 5, 40225 Düsseldorf, Germany.

Presented in part at the 17th Scientific Congress of the European Society for Pediatric Hematology and Immunology, Washington, D.C., U.S.A., May 11-15, 1999.

Published in abstract form in Pediatric Research 45:744, 1999. different subclasses of $\mathrm{IgG}, \operatorname{IgA}$, and $\mathrm{C} 3 \mathrm{~b}$ receptors and synthesize various humoral defensive factors such as complement factors, lactoferrin, and lysozyme (1-5).

Because human $\mathrm{MM} \Phi$ remain viable in conditions similar to those in the small intestine (6), show relative resistance to an environment with a $\mathrm{pH}<3$, and resist trypsinization (7), it seems very likely that $\mathrm{MM} \Phi$ can develop their immunoprotective functions within the gastrointestinal tract of the breast-fed baby.

Interaction of macrophage membrane receptors with complementary coating substances on a pathogen's surface is well described as opsonophagocytosis. These coatings (opsonins), derived from various sites of the hosts immune system, consist of bridging serum factors such as Ig, the iC $3 \mathrm{~b}$ fragment of $\mathrm{C} 3$ complement factor, C-reactive protein, surfactant proteins A and $\mathrm{D}$, and the mannose-binding protein (8).

Interaction of carbohydrate-binding proteins termed lectins with complementary carbohydrate chains is another primary mechanism of mediating attachment of pathogens. This phago- 
cytic process, known as serum independent or lectinophagocytosis, is promoted, for example, through the MR or a lectin site on the $\mathrm{CD} 11 \mathrm{~b} / \mathrm{CD} 18$ (MAC-1) integrin, the $\beta$-glucan receptor (8).

After recognition and attachment of pathogenetic particles, the process of phagocytosis progresses with different patterns of internalization and mostly culminates in the triggering of the respiratory burst with the release of microbicidal oxygen metabolites. It is hypothesized that due to a lower availability of opsonizing factors in the milk (9) and the gastrointestinal tract of the infant, human $\mathrm{MM} \Phi$ are activated by other mechanisms than BMo.

Therefore, this study was undertaken to investigate opsonoand lectinophagocytic properties of human $М M \Phi$ by measuring the superoxide anion $\left(\mathrm{O}_{2}^{-}\right)$production in comparison with human BMo after stimulation with opsonized and unopsonized zymosan particles. D-Mannose and cytochalasin B as potential inhibitors were used to evaluate attachment and engulfment mechanisms.

\section{METHODS}

\section{Collection, Preparation, and Culture of Cells}

Human milk was collected from 38 healthy lactating women 1-6 d postpartum by hand expression with informed consent at the Department of Gynecology and Obstetrics, HeinrichHeine-Universität Düsseldorf, Germany, after having obtained approval of the Clinic's Review Board. The samples were generally obtained before the infants were fed and stored at room temperature for up to $4 \mathrm{~h}$ in sterile containers.

The milk was skimmed by 1:1 dilution with PBS and centrifuged at $4^{\circ} \mathrm{C}$ and $600 \times g$ for $10 \mathrm{~min}$. The pellet was resuspended in $25 \mathrm{~mL}$ PBS, layered on $25 \mathrm{~mL}$ Ficoll-Hypaque (Pharmacia, Uppsala, Sweden), and centrifuged at $20^{\circ} \mathrm{C}$ and $1000 \times g$ for $20 \mathrm{~min}$. The mononuclear interface cell layer was washed in PBS and RPMI (GIBCO, NY, U.S.A.) (supplemented with penicillin, gentamicin, HEPES, FCS, and glutamine) and resuspended in RPMI (with supplements). Purity ( $>90 \%)$ of the cell preparation was assessed by naphthyl acetate esterase staining. Cells were enumerated by cell counter (Coulter, Krefeld, Germany) and adjusted at a concentration of $2.5 \times$ $10^{5}$ cells $/ \mathrm{mL}$. Monocytic viability of $\geq 95 \%$ was assured by trypan blue exclusion. Two milliliters of the cell suspension were prepared in plastic culture dishes, and cells were allowed to adhere for $2 \mathrm{~h}$ at $37^{\circ} \mathrm{C}$ and $5 \% \mathrm{CO}_{2}$, then washed vigorously with PBS to remove nonadherent cells.

Monocytes were isolated from heparinized human blood from 64 healthy volunteers as described above by FicollHypaque gradient and then treated like the $М M \Phi$.

The protein content in the samples was determined according to the method of Lowry et al. (10). Only samples with a protein content between 40 and $100 \mu \mathrm{g}$ were used (11). The cells were stored in PBS on ice (maximum, 15 min) until use.

\section{$\mathrm{O}_{2}^{-}$Production}

$\mathrm{O}_{2}^{-}$production was measured by reduction of superoxide dismutase-sensitive cytochrome $c$. Addition of $2 \mathrm{~mL} \mathrm{~N}$ - ethylmaleimide stopped the induced oxidative metabolism after treatment with the stimulants for $30 \mathrm{~min}$. Reduction of cytochrome $c$ was quantified spectrophotometrically $(550 \mathrm{~nm})$. The assay was repeated with superoxide dismutase to correct for oxygen-independent reduction of cytochrome $c$. Results were expressed in nmol $\mathrm{O}_{2}^{-} / \mathrm{mg}$ protein.

\section{Stimulating Agents}

Opsonized and unopsonized zymosan (Sigma Chemical Co., St. Louis, MO, U.S.A.) was used as a stimulus. Serum from healthy donors was taken for opsonization. The zymosan particles were autoclaved for $30 \mathrm{~min}$, washed twice with PBS, and resuspended in PBS. The samples were adjusted to $2 \times 10^{5}$ particles $/ \mu \mathrm{L}$ and stored at $-70^{\circ} \mathrm{C}$ until further use.

\section{Inhibitors}

Mannose and cytochalasin B (Sigma Chemical Co., St. Louis, U.S.A.) were used as potential inhibitors. Two milliliters of each substance was incubated with the isolated cells for $15 \mathrm{~min}$ at $37^{\circ} \mathrm{C}$ before the stimulation assay. Mannose was prepared in $0.1,0.25$, and $0.5-\mathrm{M}$ solutions, and cytochalasin B was used at a concentration of $1 \mu \mathrm{g} / \mathrm{mL}$. All assays were performed in duplicate.

\section{Expression of MR}

Phagocytes were stained with a monoclonal murine antibody generated against the human MR (Pharmingen, San Diego, CA, U.S.A.). BMo and $\mathrm{MM} \Phi$ were prepared as described above and subsequently incubated with the anti-MR antibodies (20 $\mu \mathrm{L}$ per pellet) for $10 \mathrm{~min}$, washed with PBS, and centrifuged at $300 \times g$ for $10 \mathrm{~min}$ at $20^{\circ} \mathrm{C}$. Staining was evaluated using a fluorescence microscope (Zeiss Optics, Göttingen, Germany).

\section{Statistical Analysis}

Statistical analysis was performed by using the paired $t$ test. An $\alpha$ error of $p<0.05$ was regarded as significant.

\section{RESULTS}

\section{Stimulation without Inhibitors}

Without any additional stimuli, a $\mathrm{O}_{2}^{-}$production of $40 \pm 3$ $\mathrm{nmol} \mathrm{O}_{2}^{-} \cdot \mathrm{mg} \mathrm{p}^{-1} \cdot 30^{1-1}$ in MMФ and $47 \pm 4.7 \mathrm{nmol} \mathrm{O}_{2}^{-} \cdot \mathrm{mg}$ $\mathrm{p}^{-1} \cdot 30^{1-1}$ in BMo was measured. After stimulation with opsonized zymosan, BMo generated $417 \pm 79 \mathrm{nmol} \mathrm{O}_{2}^{-} \cdot \mathrm{mg}$ $\mathrm{p}^{-1} \cdot 30^{\prime-1}$, and MMФ generated $216 \pm 15 \mathrm{nmol} \mathrm{O}_{2}^{-} \cdot \mathrm{mg} \mathrm{p}^{-1} \cdot 30^{\prime-1}$. When unopsonized zymosan was used, BMo produced $150 \pm$ $35 \mathrm{nmol} \mathrm{O}{ }_{2}^{-} \cdot \mathrm{mg} \mathrm{p}^{-1} \cdot 30^{\prime-1}$, and МMФ generated $176 \pm 18 \mathrm{nmol}$ $\mathrm{O}_{2}^{-} \cdot \mathrm{mg} \mathrm{p}^{-1} \cdot 30^{-1}$. Thus, peripheral BMo released a higher absolute amount of $\mathrm{O}_{2}^{-}$than human $M M \Phi$ when stimulated with opsonized zymosan, whereas $\mathrm{O}_{2}^{-}$production after activation with unopsonized zymosan demonstrated approximately equal release of the measured oxygen metabolites. Notably, MMФ showed a significantly higher proportion of $\mathrm{O}_{2}^{-}$generation under opsonin-independent stimulation (100 to $82 \%$ ) than 
BMo (100 to $36 \%$ ) in relation to opsonin-dependent stimulation (Fig. 1).

\section{Stimulation after Preincubation with Mannose}

After addition of D-mannose before stimulation with opsonized zymosan, BMo reacted with a significant reduction in $\mathrm{O}_{2}{ }^{-}$ generation $\left(302 \pm 62,247 \pm 58\right.$, and $162 \pm 53 \mathrm{nmol} \mathrm{O}_{2}^{-} \cdot \mathrm{mg}$ $\mathrm{p}^{-1} \cdot 30^{1-1}$ for $0.1,0.25$, and $0.5 \mathrm{M}$ mannose, respectively; $0.5 \mathrm{M}$ mannose: $61 \%, p<0.0025)$. MMФ showed lower $\mathrm{O}_{2}^{-}$production $\left(139 \pm 18,84 \pm 14\right.$, and $39 \pm 1 \mathrm{nmol} \mathrm{O}_{2}^{-} \cdot \mathrm{mg} \mathrm{p}^{-1} \cdot 30^{\prime-1}$ after preincubation with the above-mentioned concentrations of D-mannose, respectively; $0.5 \mathrm{M}$ mannose: $82 \%, p<$ $0.0005)$. These results suggest that $М M \Phi$ can be inhibited to a greater extent by mannose than BMo under conditions of serum opsonization (Fig. 2).

Preincubation of D-mannose after stimulation with unopsonized zymosan revealed a decrease in $\mathrm{O}_{2}{ }^{-}$output in BMo $(89 \pm$ $15,63 \pm 11$, and $30 \pm 5 \mathrm{nmol}{ }_{2}^{-} \cdot \mathrm{mg} \mathrm{p}^{-1} \cdot 30^{\prime-1}$ for $0.1,0.25$, and $0.5 \mathrm{M}$ mannose, respectively; $0.5 \mathrm{M}$ mannose: $80 \%, p<$ $0.05)$ and a reduction in $\mathrm{MM} \Phi(99 \pm 13,58 \pm 7$, and $32 \pm 5$ nmol $\mathrm{O}_{2}^{-} \cdot \mathrm{mg} \mathrm{p}^{-1} \cdot 30^{\prime-1} ; 0.5 \mathrm{M}$ mannose: $\left.82 \%, p<0.0005\right)$. Thus, no significant difference could be found between the two cell populations when unopsonized zymosan was used (Fig. 3).

\section{Stimulation after Preincubation with Cytochalasin B}

After the cells were treated with cytochalasin B $(1 \mu \mathrm{g} / \mathrm{mL})$, a significant reduction of $\mathrm{O}_{2}^{-}$generation was detected. When they were stimulated with opsonized zymosan, we found that BMo showed a decrease from $355 \pm 27$ to $264 \pm 32 \mathrm{nmol}$ $\mathrm{O}_{2}{ }^{-} \cdot \mathrm{mg} \mathrm{p}^{-1} \cdot 30^{1-1}(p<0.0005)$, whereas MMФ exhibited a decrease from $214 \pm 24$ to $131 \pm 14 \mathrm{nmol} \mathrm{O}_{2}^{-} \cdot \mathrm{mg} \mathrm{p}^{-1} \cdot 30^{\prime-1}(p$ $<0.005)$. When unopsonized zymosan was used as a stimulant, a decrease from $150 \pm 14$ to $111 \pm 13 \mathrm{nmol} \mathrm{O}_{2}^{-} \cdot \mathrm{mg}$ $\mathrm{p}^{-1} \cdot 30^{1-1}$ was detected in the BMo population $(p<0.0005)$, whereas ММФ displayed a reduction from $205 \pm 6$ to $125 \pm$

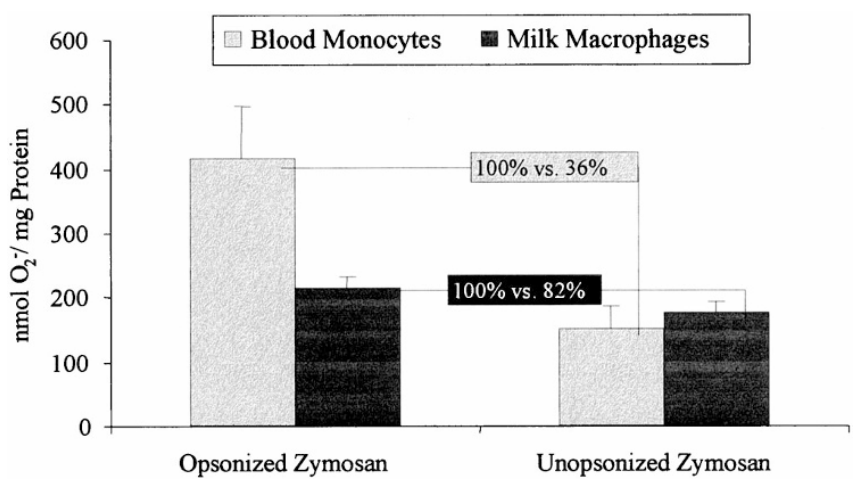

Figure 1. $\mathrm{O}_{2}^{-}$production ( $\mathrm{nmol} \mathrm{O}_{2}^{-} \cdot \mathrm{mg} \mathrm{p}^{-1} \cdot 30^{\prime-1}$ ) of BMo and MM $\Phi$ after incubation with opsonized and unopsonized zymosan without addition of inhibitors. BMo showed an almost equal generation of $\mathrm{O}_{2}{ }^{-}$to $\mathrm{MM} \Phi$ after stimulation with unopsonized zymosan, whereas release of $\mathrm{O}_{2}{ }^{-}$was markedly higher when stimulated with opsonized zymosan. When $\mathrm{O}_{2}{ }^{-}$production was compared in each cell subpopulation, the proportion of serum-independent stimulation was significantly higher in ММФ ( $82 \%$ in $М М \Phi, 36 \%$ in BMo compared with challenge with opsonized zymosan).

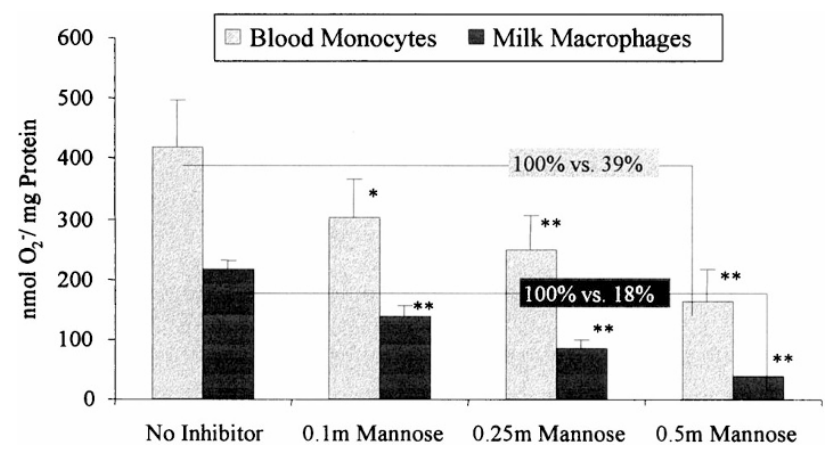

Figure 2. $\mathrm{O}_{2}^{-}$production $\left(\mathrm{nmol} \mathrm{O}_{2}^{-} \cdot \mathrm{mg} \mathrm{p}^{-1} \cdot 30^{1-1}\right)$ of BMo and $\mathrm{MM} \Phi$ after incubation with opsonized zymosan as a serum-dependent stimulus after addition of either $0.1,0.25$, or $0.5 \mathrm{M}$ D-mannose. Treatment with increasing doses of mannose resulted in decreased production of $\mathrm{O}_{2}^{-}$in both types of phagocytes. Inhibition of $\mathrm{O}_{2}^{-}$output was significantly greater in $M M \Phi$ than in BMo compared with stimulation without mannose; when $0.5 \mathrm{M}$ mannose was applied, a reduction of $82 \%$ was detected in $\mathrm{MM} \Phi$, whereas BMo reacted with a decrease of $61 \%$ in $\mathrm{O}_{2}^{-}$generation $\left(* p<0.05,{ }^{*} p<0.005\right)$.

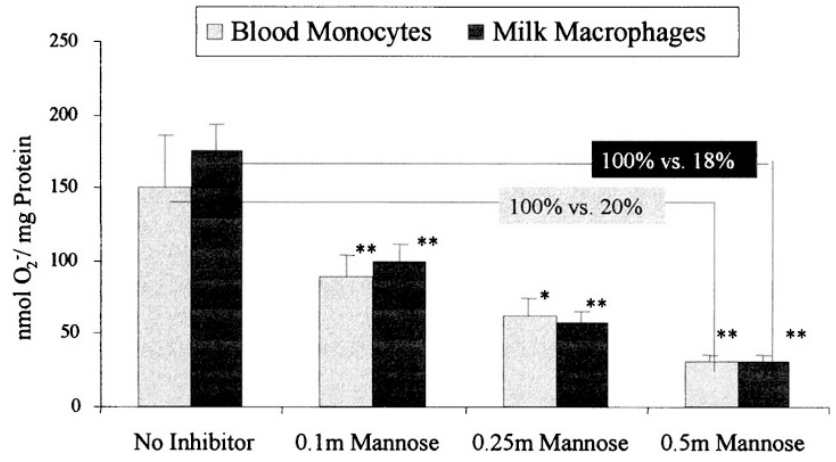

Figure 3. $\mathrm{O}_{2}^{-}$production $\left(\mathrm{nmol} \mathrm{O}_{2}^{-} \cdot \mathrm{mg} \mathrm{p}^{-1} \cdot 30^{\prime-1}\right)$ of BMo and MMФ after incubation with unopsonized zymosan as a serum-independent stimulus after addition of either $0.1,0.25$, or $0.5 \mathrm{M}$ D-mannose. Both cell populations reacted with a comparable decrease in $\mathrm{O}_{2}{ }^{-}$output after pretreatment with D-mannose in relation to stimulation without inhibitor, $82 \%$ in $\mathrm{MM} \Phi$ and $80 \%$ in BMo after preincubation with $0.5 \mathrm{M}$ mannose $\left(* p<0.05,{ }^{* *} p<0.005\right)$.

$21 \mathrm{nmol}{ }_{2}^{-} \cdot \mathrm{mg} \mathrm{p}^{-1} \cdot 30^{1-1}(p<0.025)$. We found no significant difference in the inhibition of $\mathrm{O}_{2}{ }^{-}$release induced by cytochalasin $\mathrm{B}$ regardless of the cell type or stimulus used (Fig. 4).

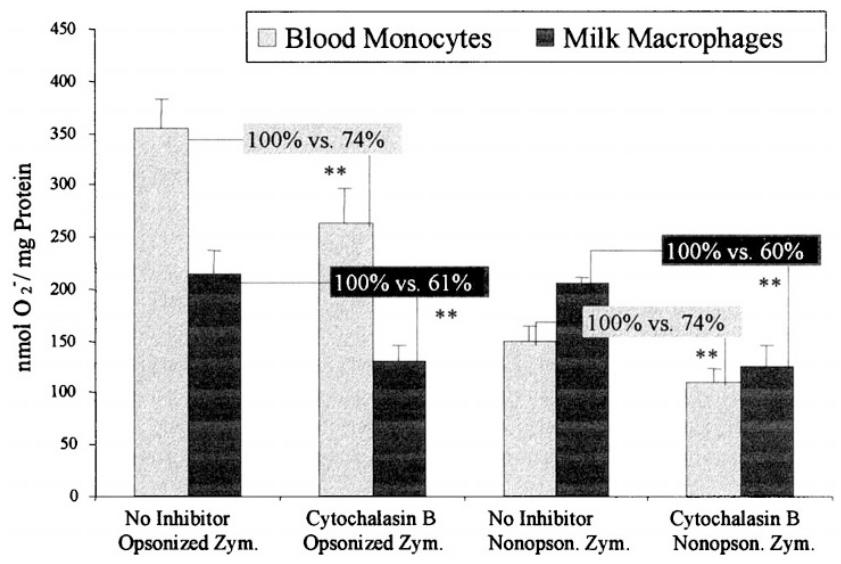

Figure 4. $\mathrm{O}_{2}{ }^{-}$production of $\mathrm{BMo}$ and $\mathrm{MM} \Phi$ after incubation with opsonized and unopsonized zymosan after addition of cytochalasin B. Pretreatment with the cytoskeleton inhibitor resulted in comparable inhibition of $\mathrm{O}_{2}{ }^{-}$production in both BMo and $\mathrm{MM} \Phi(* * p<0.005)$. 


\section{Detection of MR}

Detection of the MR on MM $\Phi$ was performed by fluorescent staining using $\mathrm{MAb}$ directed against this recognition site. Only MM $\Phi$ showed an expression of the MR.

\section{DISCUSSION}

\section{Stimulation without Inhibitors}

Different from our findings in which we demonstrated a higher proportion of opsonin-independent stimulation in $\mathrm{MM} \Phi, \mathrm{O}_{2}{ }^{-}$production in human $\mathrm{MM} \Phi$ has been reported to be equal to BMo after stimulation with phorbol myristate acetate or opsonized zymosan $(7,12,13)$. These results, though, were related to the amount of cells in the sample $\left(\mathrm{nmol} \mathrm{O}_{2}^{-1 / 5} \times\right.$ $10^{5}-10^{6}$ cells). Because $\mathrm{MM} \Phi$ are much bigger in diameter than monocytes and thus have a larger surface area, a greater number of relevant receptors per cell could account for a bias within these investigations, as $\mathrm{O}_{2}^{-}$production in $\mathrm{MM} \Phi$ may be elevated. Given that variability in the measurement of $\mathrm{O}_{2}{ }^{-}$ production occurs in samples with a protein content below 35 $\mu \mathrm{g}$ protein (14), the $\mathrm{O}_{2}{ }^{-}$generation was related to the absolute amount of protein instead of the quantity of cells.

Different patterns of receptors on the surface of the phagocytes regarding their number or quality (e.g. Fc receptor and $\mathrm{CR} 3$ on one hand, MR and $\beta$-glucan receptor on the other) could be a possible indication for the propagated specialization of ММФ. Reduced amount of opsonins (such as complement and Ig) in the colostrum (9) and the gastrointestinal tract of the neonate might lead to a relatively better serum-independent stimulation of MMФ.

\section{Stimulation after Preincubation with Mannose}

Unopsonized zymosan. Zymosan as a derivative of the cell wall of Saccharomyces cerevisiae is composed of $\alpha$-D-mannan and $\beta$-D-glucan, two carbohydrate polymers, with glucan being the most abundant component $(15,16)$. Binding and phagocytosis of unopsonized zymosan was reported to be dependent on the expression of the MR on human (17) and murine macrophages $(18,19)$. Other studies showed the dependency of $\mathrm{O}_{2}^{-}$ release in murine and rabbit macrophages on the MR $(20,21)$.

Besides difficulties in the direct transfer of research results derived from different species, some aspects of our study indicate that the MR may not play a major role; rather, another type of membrane receptor may be responsible for zymosan signaling and consecutive respiratory-burst activities in human BMo and $\mathrm{MM} \Phi$.

Monocytes do not express the MR until they are cultured for several days $(22,23)$. We confirmed this by demonstrating negative staining of BMo with FITC-labeled anti-human MR $\mathrm{MAb}$ within the cultivation periods of monocytes used in our experiments. MMФ, in contrast, do bear MR on their membrane as determined in this study by staining with MAb.

In our assay, both types of cells produced approximately equal amounts of $\mathrm{O}_{2}^{-}$when challenged with zymosan particles without any opsonizing serum factors. Addition of D-mannose in different concentrations resulted in inhibition of $\mathrm{O}_{2}^{-}$release to the same extent in both types of cells. This same reaction to stimulation and inhibition by both types of phagocytes (one being devoid of the $\mathrm{MR}$, one being equipped with it) render an involvement of this type of receptor unlikely in the production of $\mathrm{O}_{2}^{-}$.

These findings are supported by a recent report of AstarieDequeker et al. (24) who showed that phagocytosis of unopsonized zymosan through the MR did not result in triggering of $\mathrm{O}_{2}{ }^{-}$production. These investigators could demonstrate that the uptake of zymosan particles by human monocyte-derived macrophages was dependent on the MR as well as on another membrane component, the $\beta$-glucan receptor, which is located on the complement receptor type 3 (CR3). Even though the internalization of unopsonized zymosan was also mediated by the MR, an observation that has been confirmed by Lombard et al. (25), the $\mathrm{O}_{2}{ }^{-}$generation itself was triggered only by phagocytosis via the $\beta$-glucan receptor.

This lectin-like $\beta$-glucan receptor has been located on the $\alpha_{\mathrm{m}} \beta_{2}$ integrin CR3 (CD11b/CD18, Mac-1), which is composed of the $\alpha(\mathrm{CD} 11 \mathrm{~b})$ and $\beta$ (CD18) subunits. The $\beta$-glucan site was found to be situated on the $\alpha$ chain $\mathrm{C}$-terminal to the I-domain, distinct from the binding sites for iC 3b, ICAM-1, fibrinogen, and clotting factor X $(26,27)$.

Our results (with stimulation by unopsonized zymosan and inhibition with d-mannose to the same extent in both types of cells) could be the consequence of a comparable distribution of the $\beta$-glucan receptor on BMo and MMФ because the MR does not seem to be involved in the release of $\mathrm{O}_{2}{ }^{-}$anions. Considering the sugar specificity of this lectin site, the demonstrated concentration-dependent functional impairment of zymosaninduced $\mathrm{O}_{2}{ }^{-}$production could be explained by the inhibition of the $\beta$-glucan receptor by D-mannose. Supporting this, an investigation by Thornton et al. (28) revealed the lectin site of CR3 to have a broader specificity for certain polysaccharides than originally appreciated. In this regard, SZP, a soluble zymosan polysaccharide, which blocked the binding site to the same extent as various $\beta$-glucan preparations, was unexpectedly found to consist primarily of mannose.

Opsonized zymosan. A greater mannose-exerted inhibition of $\mathrm{O}_{2}{ }^{-}$production in $M M \Phi$ and a suggested similar expression of $\beta$-glucan/CR3 receptors in the two cell populations lead to the conclusion that a different type of opsonin receptor being disproportionally distributed accounts for the effect of this uneven stimulation and inhibition in connection with opsonized zymosan.

In this respect, a decreased expression of all three subclasses of $\mathrm{Fc}$ receptors (CD16, CD32, CD64) on $\mathrm{MM} \Phi$ has been described by Rivas et al. (14). Participation of $\mathrm{Ig}$ in the opsonization of zymosan has been demonstrated in a study on respiratory burst in human granulocytes (29). Even zymosanspecific IgG antibodies have been identified to enhance alternative pathway activities in human serum (30).

Especially, complement factors such as $\mathrm{C} 3 \mathrm{~b}$ or $\mathrm{iC} 3 \mathrm{~b}$ are necessary in the opsonization of zymosan (31). A concerted interaction between CR3 and the $\beta$-glucan lectin site (with the complement receptor being the primary binding site and the $\beta$-glucan receptor being the function-triggering moiety) has been postulated in the synthesis of platelet-activating factor in human monocytes (32). Moreover, in human neutrophils, binding of complement-opsonized yeast is related to the binding 
site for $\mathrm{iC} 3 \mathrm{~b}$ on $\mathrm{CR} 3$, whereas ingestion and respiratory burst depend on coupling with the $\beta$-glucan binding site (33).

Monocytes and MMФ have been shown to secrete essential factors for activation and propagation of the alternative complement pathway $(1,34)$, so they are capable of local zymosan opsonization via autocrine liberation of complement factors (35, 36).

Taken together, two major opsonin-dependent receptors with different distributions, the CR3 receptor being expressed approximately to the same extent in both cell types and the Fc receptor being more abundant on the surface of BMo, may be responsible for the results found in our studies.

\section{Stimulation after Preincubation with Cytochalasin B}

In our experiments, both $\mathrm{MM} \Phi$ and BMo reacted with an almost equal reduction in $\mathrm{O}_{2}^{-}$generation after treatment with cytochalasin B when stimulated with either opsonized or unopsonized zymosan. These findings suggest comparable engulfment mechanisms of foreign particles in these phagocyte populations that seem to be dependent on an intact microfilamentous system.

Cytoskeletal integrity has been shown to be required for internalization of opsonized particles such as formation of phagosomes or lamellipodia (37). Cytochalasin B, as an agent to disrupt microfilaments by interfering with actin polymerization, was reported to inhibit endocytosis $(38,39)$, degradation of proteins by macrophages (40), and formation of foreign-body giant cells by macrophages (41), so an interference with the production of reactive oxygen metabolites seems possible as well.

In summary, we find that the macrophage population in human milk is capable of reacting with the release of $\mathrm{O}_{2}^{-}$to both opsonized and unopsonized particles with a higher proportion of serum-independent phagocytosis. The higher amount of these "lectinophagocytic" responses possibly reflects the specialization of these phagocytes to the specific neonatal environment.

Acknowledgment. The authors thank Dr. Beth A. McCormick, Massachusetts General Hospital, Boston, MA, U.S.A., for critical reading of the manuscript and helpful comments.

\section{REFERENCES}

1. Goldman AS, Goldblum RM 1997 Transfer of maternal leukocytes to the infant by human milk. Curr Top Microbiol Immunol 222:205-213

2. Schroten H, Uhlenbruck G, Hanisch FG, Mil A 1987 Varying rates of phagocytosis of human blood monocytes and breast milk macrophages: effect of intralipid and milk fat globules. Monatsschr Kinderheilkd 135:36-40

3. Ogra PK, Greene HL 1982 Human milk and breast-feeding: an update on the state of the art. Pediatr Res 16:266-271

4. Cole FS, Schneeberger EE, Lichtenberg NA, Colten HR 1982 Complement biosynthesis in human breast milk macrophages and blood monocytes. Immunology 46:429-441

5. Speer CP, Hein-Kreikenbaum H 1993 Immunologic importance of breast milk. Monatsschr Kinderheilkd 141:10-20

6. Blau H, Passwell H, Levanon M, Davidson J, Kohen F, Ramot B 1983 Studies on human milk macrophages: effect of activation on phagocytosis and secretion of prostaglandin E2 and lysozyme. Pediatr Res 17:241-245

7. Speer CP, Gahr M, Pabst MJ 1986 Phagocytosis-associated oxidative metabolism in human milk macrophages. Acta Paediatr Scand 74:444-451

8. Ofek I, Goldhar J, Keisari Y 1995 Nonopsonic phagocytosis of microorganisms. Annu Rev Microbiol 49:239-276

9. Vassao RC, Carneiro-Sampaio MM 1989 Phagocytic activity of human colostrum macrophages. Braz J Med Biol Res 22:457-464

10. Lowry OH, Rosebrough NJ, Farr AL, Randall RJ 1951 Protein measurement with the Folin phenol reagent. J Biol Chem 193:265-275
11. Johnston RB, Godzik CA, Cohn ZA 1978 Increased superoxide anion production by immunologically activated and chemically elicited macrophages. J Exp Med 148:115-127

12. Tsuda H, Dickey WD, Goldman AS 1984 Separation of human colostral macrophages and neutrophils on gelatin and collagen serum substrata. Cell Struct Funct 8:367-371

13. Cummings NP, Neifert MR, Pabst MJ, Johnston RB 1985 Oxidative metabolic response and microbicidal activity of human milk macrophages: effect of lipopolysaccharide and muramyl dipeptide. Infect Immun 49:435-439

14. Rivas RA, El-Mohandes AA, Katona IM 1994 Mononuclear phagocytic cells in human milk: HLA-DR and Fc gamma R ligand expression. Biol Neonate 66:195-204

15. Di Carlo FJ, Fiore JV 1958 On the composition of zymosan. Science 127:756-757

16. Bacon JSD, Farmer VC, Jones D, Taylor IF 1969 The glucan components of the cell wall of baker's yeast (Saccharomyces cerevisiae) considered in relation to its ultrastructure. Biochem J 114:557-567

17. Speert DP, Silverstein SC 1985 Phagocytosis of unopsonized zymosan by human monocyte-derived macrophages: maturation and inhibition by mannan. J Leukoc Biol 38:655-658

18. Warr GA 1980 A macrophage receptor for (mannose/glucosamine)-glycoproteins of potential importance in phagocytic activity. Biochem Biophys Res Commun 93:737-745

19. Sung SJ, Nelson RS, Silverstein SC 1983 Yeast mannans inhibit binding and phagocytosis of zymosan by mouse peritoneal macrophages. J Cell Biol 96:160-166

20. Berton G, Gordon S 1983 Modulation of macrophage mannosyl-specific receptors by cultivation on immobilized zymosan. Effects on superoxide-anion release and phagocytosis. Immunology 49:705-715

21. Klegeris A, Budd TC, Greenfield SA 1996 Acetylcholinesterase-induced respiratory burst in macrophages: evidence for the involvement of the macrophage mannosefucose receptor. Biochim Biophys Acta 1289:159-168

22. Ezekowitz RA, Sastry K, Bailly P, Warner A 1990 Molecular characterization of the human macrophage mannose receptor: demonstration of multiple carbohydrate recognition-like domains and phagocytosis of yeasts in Cos-1 cells. J Exp Med 172:1785-1794

23. Stahl PD, Ezekowitz RA 1998 The mannose receptor is a pattern-recognition receptor involved in host defense. Curr Opin Immunol 10:50-55

24. Astarie-Dequeker C, N'Diaye E, Le Cabec V, Rittig MG, Prandi J, MaridonneauParini I 1999 The mannose receptor mediates uptake of pathogenic and nonpathogenic mycobacteria and bypasses bactericidal responses in human macrophages. Infect Immun 67:469-477

25. Lombard Y, Giamis J, Makaya-Kumba M, Fonteneau P, Poindron P 1994 A new method for studying the binding and ingestion of zymosan particles by macrophages. J Immunol Methods 174:155-165

26. Czop JK, Austen KF 1985 A beta-glucan inhibitable receptor on human monocytes: its identity with the phagocytic receptor for particulate activators of the alternative complement pathway. J Immunol 134:2588-2593

27. Diamond MS, Garcia-Aguilar J, Bickford JK, Corbi AL, Springer TA 1993 The I domain is a major recognition site on the leukocyte integrin Mac-1 (CD11b/CD18) for four distinct adhesion ligands. J Cell Biol 120:1031-1043

28. Thornton BP, Vetvicka V, Pitman M, Goldman RC, Ross GD 1996 Analysis of the sugar specificity and molecular location of the $\beta$-glucan-binding lectin site of complement receptor type 3 (CD11b/CD18). J Immunol 156:1235-1246

29. Cheson BD, Morris SE 1981 The role of complement and IgG on zymosan opsonization. Int Arch Allergy Appl Immunol 66:48-54

30. Schenkein HA, Ruddy S 1981 The role of immunoglobulins in alternative complement pathway activation by zymosan. I. Human IgG with specificity for zymosan enhances alternative pathway activation by zymosan. J Immunol 126:7-10

31. Xia Y, Vetvicka V, Yan J, Hanikyrova M, Mayadas T, Ross GD 1999 The $\beta$-glucan binding lectin site of mouse CR3 (CD11b/CD18) and its functions in generating a primed state of the receptor that mediates cytotoxic activation in response to iC $3 \mathrm{~b}$ opsonized target cells. J Immunol 162:2281-2290

32. Elstad MR, Parker CJ, Cowley FS, Wilcox LA, McIntyre TM, Prescot SM, Zimmerman GA $1994 \mathrm{CD} 11 \mathrm{~b} / \mathrm{CD} 18$ integrin and a beta-glucan receptor act in concert to induce the synthesis of platelet-activating factor by monocytes. J Immunol 152:220-230

33. Cain JA, Newman SL, Ross GD 1987 Role of complement receptor type three and serum opsonins in the neutrophil response to yeast. Complement 4:75-86

34. Hetland G, Eskeland T 1986 Formation of the functional alternative pathway of complement by human monocytes in vitro as demonstrated by phagocytosis of agarose beads. Scand J Immunol 23:301-308

35. Ezekowitz RA, Sim RB, Hill M, Gordon S 1984 Local opsonization by secreted macrophage complement components. Role of receptors for complement in uptake of zymosan. J Exp Med 159:244-260

36. Ezekowitz RA, Sim RB, MacPherson GG, Gordon S 1985 Interaction of human monocytes, macrophages, and polymorphonuclear leukocytes with zymosan in vitro. Role of type 3 complement receptors and macrophage-derived complement. J Clin Invest 76:2368-2376

37. Allen L, Aderem A 1996 Molecular definition of distinct cytoskeletal structures involved in complement- and $\mathrm{Fc}$ receptor-mediated phagocytosis in macrophages. J Exp Med 184:627-637

38. Newman SL, Mikus LK, Tucci MA 1991 Differential requirements for cellular cytoskeleton in human macrophage complement receptor- and Fc receptor-mediated phagocytosis. J Immunol 146:967-974

39. Allison AC, Davies P, De Petris S 1971 Role of contractile microfilaments in macrophage movement and endocytosis. Nat New Biol 232:153-155

40. Dean RT 1979 Effects of cytochalasin B on the pinocytosis and degradation of proteins by macrophages. Biochem Soc Trans 7:362-364

41. DeFife K, Jenney C, Colton E, Anderson J 1999 Disruption of filamentous actin inhibits human macrophage fusion. FASEB J 13:823-832 